\title{
Prevalence of virulence genes among VRE genotypes and their association with clinical outcome
}

\author{
Ramamurthi Arularasi Aberna ${ }^{1 *}$, Kesani Prabhakar ${ }^{2}$ \\ From 2nd International Science Symposium on HIV and Infectious Diseases (HIV SCIENCE 2014) \\ Chennai, India. 30 January - 1 February 2014
}

\section{Background}

The dramatic upsurge in the incidence of VRE worldwide had contributed serious concerns in early and specific diagnosis, infection control measures and treatment. There exists a paucity of information regarding VRE genotypes and their virulence genes contributing to disease severity in India. This study determines the prevalence of VRE and the role of four virulence genes in their clinical outcome.

\section{Methods}

Enterococci were isolated from a total of 2500 clinical specimens and species identification was done based on conventional methods. VRE were confirmed by agar dilution (vancomycin and teicoplanin) and by the presence of $v a n A / v a n B$ genes. The presence of esp, agg, gelE and $c y l A$ gene among VRE were detected by PCR.

\section{Results}

VRE were isolated from $7.3 \%$ of clinical specimens. VR E.faecalis and VR E.faecium were primarily derived from UTI and BSI (56.7\% and 43.3\%) respectively. Among the VRE isolates, $80 \%$ of vanA genes were noted in E.faecium and $64 \%$ of $v a n B$ genes were observed in E.faecalis. Most of VR E.faecalis harboured 2 virulence genes (38.5\%) and VR E.faecium harboured one virulence gene (62.5\%). The ability to cause invasive infections increased with the number of virulence genes harboured by E.faecalis. An association was observed between the presence of virulence gene esp, cylA and agg with UTI, BSI and IAP infections respectively among the VRE isolates.

\footnotetext{
* Correspondence: arularasiaberna@gmail.com

'Rajah Muthiah Dental College and Hospital, Annamalai University,

Annamalai Nagar, India

Full list of author information is available at the end of the article
}

\section{Conclusion}

Isolation of VRE harbouring $v a n A$ and $v a n B$ gene gains significance as they are transmissible to co infecting/ resident organisms and to implement infection control measures.

\section{Authors' details}

${ }^{1}$ Rajah Muthiah Dental College and Hospital, Annamalai University, Annamalai Nagar, India. ${ }^{2}$ Rajah Muthiah Medical College and Hospital, Annamalai University, Annamalai Nagar, India.

Published: 27 May 2014

doi:10.1186/1471-2334-14-S3-P44

Cite this article as: Aberna and Prabhakar: Prevalence of virulence genes among VRE genotypes and their association with clinical outcome. BMC Infectious Diseases 2014 14(Suppl 3):P44.
Submit your next manuscript to BioMed Central and take full advantage of:

- Convenient online submission

- Thorough peer review

- No space constraints or color figure charges

- Immediate publication on acceptance

- Inclusion in PubMed, CAS, Scopus and Google Scholar

- Research which is freely available for redistribution
() Biomed Central 